\title{
Pengaruh Model Pembelajaran Level of Inquiry Berbantuan Animasi terhadap Kemampuan Berpikir Kritis dan Pemahaman Konsep Siswa pada Materi Asam Basa
}

\author{
Laili Nur Azizah $^{1}$, Munzil $^{1}$, Fauziatul Fajaroh ${ }^{1}$ \\ ${ }^{1}$ Pendidikan Kimia-Universitas Negeri Malang
}

\begin{tabular}{l}
\hline \hline INFO ARTIKEL \\
\hline Riwayat Artikel: \\
Diterima: 26-08-2019 \\
Disetujui: 21-04-2020 \\
\hline
\end{tabular}

\section{Kata kunci:}

level of inquiry; animation media; critical thinking; concept understanding;

level of inquiry;

media animasi;

berpikir kritis;

pemahaman konsep

\author{
Alamat Korespondensi: \\ Laili Nur Azizah \\ Pendidikan Kimia \\ Universtas Negeri Malang \\ Jalan Semarang 5 Malang \\ E-mail: lailinur0302@gmail.com
}

\begin{abstract}
The purpose of this study was to find out effect of learning on critical thinking skills and conceptual understanding of acid-base material. The learning model used was the Level of Inquiry. The quantitative research design using the Quasy experiment method based on the post tett only non equivalent group design was applied in the study. The results do not have a significant effect on critical thinking skills, but the use of animation media in general affects the understanding of concepts. The biggest influence is on the class with the help of dynamic media.
\end{abstract}

ABSTRAK

\begin{abstract}
Abstrak: Tujuan peneltian yang dilakukan adalah untuk mengetahui pengaruh pembelajaran terhadap kemampuan berpikir ktritis dan pemahaman konsep pada materi asam basa. Model pembelajaran yang digunakan adalah Level of Inquiry. Rancangan penelitian kuantitatif yang menggunakan metode Quasy experiment berdasarkan rancangan post tet only non equivalent group design diterapkan dalam penelitian Hasilnya tidak memberikan pengaruh yang signifikan terhadap kemampuan berpikir kritis, tetapi penggunaan media animasi secara umum berpengaruh terhadap pemahaman konsep. Pengaruh terbesar terdapat pada kelas dengan bantuan media dinamis.
\end{abstract}

Fakta berpikir kritis dalam pembelajaran kimia di Indonesia masih tergolong rendah sampai menengah (Agustin, Fadiawati, \& Tania, 2017; Ariyanti \& Masykuri, 2017; Utami, Saputro, Masykuri, \& Widoretno, 2017). Penyebabnya karena kurangnya siswa dalam mempergunakan kemampuan berpikir. Menggunakan kemampuan berpikir dalam ilmu kimia sangat diperlukan, pasalnya pelajaran tersebut berasal dari fakta dalam kehidupan sehari-hari. Kemampuan berpikir dibutuhkan dalam proses evaluasi, analisis, dan menarik simpulan berdasarkan fakta eksperimen (Utami et al., 2017). Fakta eksperimen yang dilakukan disintesis dan dipertanggungjawabkan kesimpulannya melalui proses berpikir kritis. Jika kemampuan berpikir kritis siswa tidak terpenuhi maka dalam memahami ilmu kimia secara utuh siswa merasa kesulitan. Oleh karena itu, diperlukan cara untuk meningkatkan kemampuan berpikir kritis. Langkah yang dapat dilakukan adalah menyesuaikan materi yang diajarkan dengan model pembelajaran.

Model tradisional yang menuntut hafalan dan mengingat membuat siswa kurang memahami informasi yang diberikan Pembelajaran berasaskan pengalaman dan fenomena sehari-hari diharapkan dapat mengonstruk konsep dan pembelajarannya lebih bermakna sehingga pengetahuan yang didapat siswa tersimpan dalam memori jangka panjang (Wisdawati, 2014). Model pembelajaran yang sesuai dengan hal tersebut salah satunya adalah level of inquiry. Melalui serangkaian tahapan pembelajaran dalam model tersebut proses saintifik dan intelektual siswa dapat meningkat. Tahapan pembelajaran level of inquiry, meliputi discovery learning, interactive demonstration, inquiry lab, real world application, dan hipotetical inquiry (Wenning et al., 2011). Melalui tahapan tersebut, harapannya siswa dengan mandiri mengonstruk pengetahuan secara konsep, terampil, dan aplikatif di lingkungan sekitar (Wenning, 2012). Menggunakan model Level of inquiry dapat meningkatkan pengetahuan (konten, prosedur, epistemik) dan kompetensi siswa (menjelaskan fakta dan interpreasi data percobaan) (Arief \& Utari, 2015). Peneliti lain menyebutkan bahwa kemampuan inkuiri siswa, dan ketuntasan belajar (afektif dan psikomotorik) meningkat dengan menerapkan model tersebut (Liliawati \& Hidayat, 2013). Model tersebut dapat meningkatkann pemahaman konsep fisika siswa kelas X. Akan tetapi, pada kimia untuk meningkatkan pemahaman konsep selain dengan menggunakan metode pembelajaran yang sesuai pembelajaran tersebut harus melibatkan tiga level representasi kimia (Saputra, Kade, \& Hatibe, 2017). 
Repesentasi kimia terdiri atas level makroskopik, simbolik, dan sub-mikroskopik (Treagust, Chittleborough, \& Mamiala, 2010). Siswa akan lebih paham tentang materi yang diajarkan jika guru melibatkan semua representasi tersebut. Namun faktanya, banyak guru mengajar meninggalkan level sub-mikroskopik dari pelajaran yang diajarkan dengan hanya terfokus pada level simbolik dan makroskopiknya (Kelly, Akaygun, HAnsen, \& Cerdas, 2013). Akibatnya konsep pembelajaran yang seharusnya dapat dipahami siswa tidak dapat dipahami secara maksimal. Contohnya dalam materi asam-basa, pemahaman konsep pada masing-masing sub bab masih kurang. Siswa menganggap spesi asam hanya senyawa yang menghasilkan $\mathrm{H}^{+}$. Namun sebenarnya, konsep asam-basa dapat dijelaskan berdasarkan pengertian yang lain. Oleh karena itu, diperlukan pembelajaran yang dapat menjelaskan gambaran sub-mikroskopik dari materi yang diajarkan (Nabilah, Andayani, \& Laksmiwati, 2018). Pembelajaran yang dapat melibatkan ketiga representasi kimia dapat menggunakan media dalam pembelajaram yang cocok.

Media gambar sering digunakan sebagai pelengkap pembelajaran. Menggunakan media gambar dapat menjelaskan materi yang secara kasat mata tidak dapat dijelaskan. Dengan demikian, fenomena level sub-mikroskopik dari materi kimia yang tidak dapat diamati secara kasat mata dapat dijelaskan sehingga dapat meningkatkan pemahaman konsep siswa (Bell, Maeng, \& Binns, 2013; Christopher Smith \& Villarreal, 2015; Pekdağ, 2010). Media gambar dapat berupa gambar animasi dinamis maupun gambar sederhana (animasi statis) (Ardiansyah, 2013; Barak \& Hussein-farraj, 2013; Kelly et al., 2013; Turkoguz, 2012). Fungsi keduanya sama tetapi visualisai keduanya berbeda. Gambar statis berupa gambaran sederhana yang menampilakan objek tidak bergerak (Ardiansyah, 2013). Sedangkan gambar dinamis dibuat melibatkan multimedia yang memiliki detail tertentu dalam gambarnya. Animasi statis dan dinamis dalam pembelajaran biologi efektif digunakan. Hal tersebut dibuktikan dengan meningkatnya hasil evaluasi siswa. Penelitian lain mengatakan menggunakan metode inkuiri dan media pada topik asam basa pemahaman konsep dan mental model siswa dapat meningkat (Supasorn \& Promarak, 2014).

Materi asam basa dapat diajarkan dengan menggunakan model pembelajaran level of inquiry berbantuan animasi baik animasi statis dan dinamis. Pasalnya materi asam-basa faktanya dapat diamati secara nyata, konsepnya tidak terlihat, banyak melibatkan representasi secara simbolik dan cakupan konsep yang kompleks dapat menimbulkan miskonsepsi. Selain hal tersebut hubungan materi asam-basa dengan konsep kimia lain, seperti kesetimbangan, reaksi redoks, dan larutan yang nantinya digunakan secara lebih kompleks dalam materi biokimia dan kimia organik yang dapat meningkatkan proses berpikir siswa (Nyachwaya, 2016). Berdasarkan permasalahan yang telah dituliskan, penulis menganggap perlu melakukan penelitian dalam bidang pendidikan kimia dengan judul "Pengaruh Model Level of Inquiry berbantuan Animasi terhadap Kemampuan Berpikir Kritis dan Pemahaman Konsep pada Materi Asam Basa”.

\section{METODE}

Penelitian menggunakan pendekatan kuantitatif dengan menggunakan metode Quasy experiment berdasarkan rancangan post tet only non equivalent group design. Sampel pada penelitian sebanyak tiga kelas (satu kelas kontrol dan dua kelas eksperimen) yang diambil secara acak kelas XI SMAN 1 Ngunut tahun ajaran 2018/2019. Kelas kotrol dibelajarkan dengan model level of Inquiry tanpa menggunakan animasi, kelas eksperimen A dibelajarkan dengan menggunakan Level of Inquiry dengan animasi statis dan kelas eksperimen B dibelajarkan dengan menggunakan Level of Inquiry dengan animasi dinamis.

Perangkat pembelajaran yang digunakan terdiri atas RPP, Lembar Kerja Siswa untuk semua kelas, dan media animasi untuk kelas eksperimen. Media animasi statis digunakan untuk kelas eksperimen A dan media animasi dinamis untuk kelas eksperimen B. Instrumen pengukuran terdiri atas instrumen tes berpikir kritis dan pemahaman konsep yang telah divalidasi. Instrumen tes tersebut dipakai untuk mengukur perbedaan keduanya akibat penggunaan Level of Inquiry berbantuan anumasi maupun tidak. Penilaian tes dilakukan pada akhir pertemuan.

Analisis yang dilakukan terhadap data yang terkumpul, meliputi uji prasyarat dan uji hipotesis. Uji normalitas (Normality test) dan homogenitas (Lavene Test) sebagai uji prasyarat dan anova untuk uji hipotesis. Semua analisis data tersebut dilakukan dengan menggunakan program statistika berupa SPSS.

\section{HASIL}

Kelas pada penelitian digunakan kelas yang memiliki kemampuan awal sama. Hal tersebut dilakukan supaya perbedaan pengaruh akibat perlakuan dapat teramati. Untuk mengetahui hal tersebut dilakukan analisis menggunakan uji Kruskal-Wallis $H$ pada data kemampuan awal siswa. Uji tersebut sebagai alternatif uji anova karena kemampuan awal siswa yang tidak nornal. Hasilnya menunjukan nilai sig. > 0,05, maka dapat disimpulkan kemampuan awalnya sama pada ketiga kelas. Sehingga, dapat dipastikan perbedaan nilai berasal dari perlakuannya.

Uji Kruskal-Wallis $H$ digunakan karena sesuai hasil uji prasyarat pada kemampuan awal normalitasnya sebesar 0,000; 0,022; dan 0,001 berurutan untuk kelas eksperimen A, B dan kontrol. Sedangkan uji homogenitasnya menghasilkan nilai sig. 0,599. Kedua hasil tersebut menunjukkan bahwa data kemampuan awalnya tidak normal tetapi homogen.

Data penelitian kemampuan berpikir kritis perbandingannya dapat dilihat pada gambar 1. Kemampuan berpikir kritis pada ketiga kelas tersebut saling tumpang tindih tidak memiliki perbedaan nyata. Nilai terendah pada kelas eksperimen $\mathrm{A}$ dengan nilai 30 dan tertinggi pada kelas eksperimen B dengan nilai 80. Rata-rata berpikir kritisnya kelas kontrol, eksperimen A dan B secara berurutan sebesar 51,91; 53,79; 56,67. Data tersebut nantinya akan dianalisis untuk diuji hipotesisnya. 


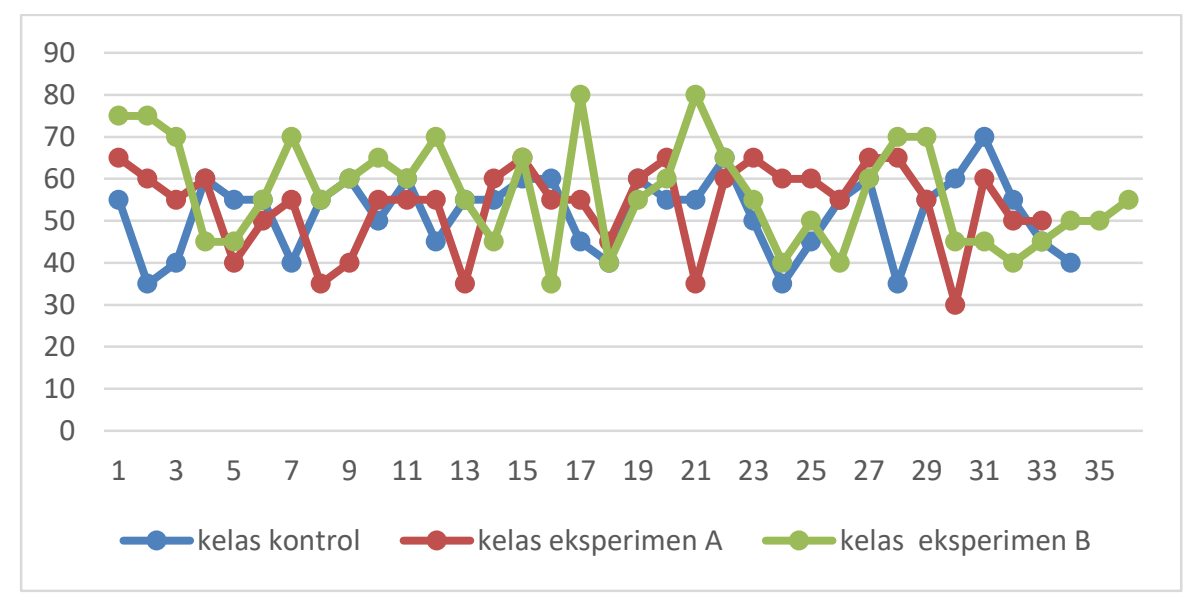

Gambar 1. Data Kemampuan Berpikir Kritis

Perbandingan nilai pemahaman disajikan pada gambar 2. Dari gambar tersebut tampak bahwa nilai pemahaman konsep siswa eksperimen B selalu diatas. Untuk kedua kelas lainnya nampak bahwa pemahaman konsep keduanya sejajar. Nilai ratarata pemahaman konsep siswa secara berurutan pada kelas kontrol, eksperimen A dan B sebesar 44, 44,09 dan 59,47. Data yang terkumpul nantinya akan dilakukan uji analisis sesuai dengan hipotesis yang diajukan.

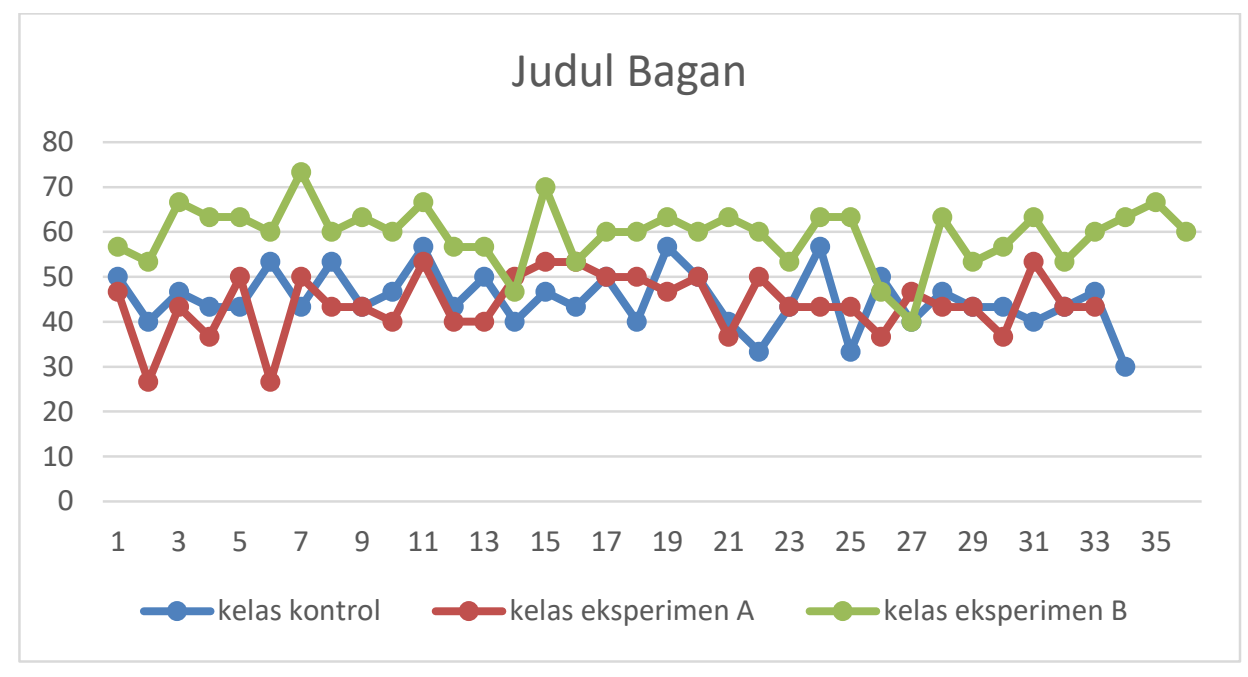

Gambar 2. Data Pemahaman Konsep

Data yang terkumpul diuji prasyarat analisis (Normalitas dan Homogenitas). Hasil uji prasyaratnya disajikan pada tabel 1. Hasilnya dapat dikatakan bahwa data tidak terdistribusi normal karena sig. $<0,05$ dan homogen karena sig. $>0,05$.

Tabel 1. Nilai Sig. Uji Normalitas dan Uji Homogenitas Hasil Percobaan

\begin{tabular}{cccc}
\hline \multicolumn{2}{c}{ Nilai Berpikir Kritis } & \multicolumn{2}{c}{ Nilai Pemahaman Konsep } \\
\hline Nilai Sig. Normalitas & Nilai Sig. Homogenitas & Nilai Sig. Normalitas & Nilai Sig. Homogenitas \\
\hline $\mathbf{0 . 0 2 7}$ & 0,131 & 0,031 & 0,832 \\
\hline
\end{tabular}

\section{Uji Hipotesis Kemampuan Berpikir Kritis}

Data pada Gambar 1 diuji hipotesis untuk mengetahui pengaruh perlakuan terhadap kemampuan berpikir kritis siswa. Ujinya dilakukan dengan uji Kruskal-Wallis $H$ karena data berpikir kritis siswa tidak memenuhi prasyarat analisis. Hasil uji secara umum dihasilkan nilai sig. sebesar 0.280. Kesimpulannya tidak terdapat pengaruh pengunaan model pembelajaran Level of Inquiry yang dipadukan media animasi terhadap berpikir kritis siswa. Hasil tersebut belum dapat menentukan model pembelajaran yang paling berpengaruh terhadap ketiganya. Oleh karena itu, perlu dilakukan uji lanjutan dengan membandingkan dua kelas. Hasilnya disajikan pada tabel 2. Hasilnya terlihat bahwa tidak terdapat kelas yang paling berpengaruh karena nilai Asymp. Sig > 0,05. 
Tabel 2. Uji Hipotesis Kemampuan Berpikir Kritis Masing-masing Kelas

\begin{tabular}{lcc}
\hline Perbandingan kelas & Asymp. Sig. & Kesimpulan \\
\hline Kontrol - eksperimen A & 0.281 & Tidak signifikan \\
Kontrol - eksperimen B & 0.142 & Tidak signifikan \\
Experimen A - eksperimen B & 0.474 & Tidak signifikan \\
\hline
\end{tabular}

Uji Hipotesis Pemahaman Konsep Siswa

Data pada Gambar 2. diuji hipotesis untuk mengetahui pengaruh perlakuan terhadap nilai pemahaman konsep. Ujinya menghasilkan nilai Asymp. Sig. < 0,05, maka dipastikan secara umum terdapat perbedaan perlakuan terhadap pemahaman konsepnya. Seperti halnya pada kemampuan berpikir kritisnya pada hasil tersebut belum menentukan perlakuan mana yang paling berpengaruh. Untuk mengetahui hal tersebut perlu dilakukan uji membandingkan antar dua kelas yang digunakan. Hasilnya dapat dilihat pada tabel 3. Berdasarkan nilai Asymp. Sig terlihat bahwa eksperimen A tidak memiliki pengaruh yang signifikan, tetapi signifikan pada kelas eksperimen B dan berbeda di kelas eksprimen A dan B.

Tabel 3. Uji Hipotesis Pemahaman Konsep

\begin{tabular}{lcc}
\hline Perbandingan kelas & Asymp. Sig. & Kesimpulan \\
\hline Kontrol - eksperimen A & 0.788 & Tidak signifikan \\
Kontrol - eksperimen B & 0.000 & Signifikan \\
Eksperimen A - eksperimen B & 0.000 & Signifikan \\
\hline
\end{tabular}

\section{PEMBAHASAN}

\section{Pengaruh Model Pembelajaran Level of Inquiry Berbantuan Media Animasi terhadap Kemampuan Berpikir Kritis}

Secara umum maupun khusus berdasarkan hasil uji hipotesis, kemampuan berpikir kritis siswa tidak signifikan ditinjau dari metode pembelajaran yang digunakan. Akan tetapi, berdasarkan rata-rata kemampuan berpikir kitis siswa berbeda. Ratarata tertinggi pada kelas eksperimen B sebesar 56,67 kemudian kelas eksperimen A sebesar 53,79. Rata-rata terkecil kelas kontrol sebesar 51,91. Hasil tersebut sesuai dengan penelitian sebelumnya, melibatkan media interaktif mempu menunjukkan peningkatan kemampuan berpikir kritis siswa (Komara, Ertikanto, \& Rosidin, 2017). Melalui model inkuiri terbimbing dengan bantuan animasi, hasil belajar siswa pada materi sistem peredaran darah (Hendriani, 2016) dan sistem gerak meningkat (Dona, 2013).

Perbedaan yang tidak signifikan antara kedua kelas tersebut kemungkinan dikarenakan oleh (1) media pembelajaran yang diberikan tidak dapat menimbulkan perbedaan berpikir kritis siswa. Media yang diberikan bersifat untuk menjelaskan bagaimana materi tersebut dapat dijelaskan secara submikroskopik sehingga tidak menimbulkan argumen yang berbeda dari siswa saat berdiskusi sehingga proses berpikir terhadap materi yang dipelajari kurang dan menimbulkan perbedaan proses berpikir kritis kurang signifikan; (2) kurang mandirinya siswa dalam proses belajar mengajar. Pada dasarnya, guru sebelumnya mengajar materi kimia secara tradisional sehingga pembelajaran terpusat pada pelajar. Sementara itu, pada penelitian ini digunakan model pembelajaran Level of Inquiry dimana siswa dituntut untuk menacari tahu sendiri materi yang diajarkan berdasarkan fakta.

\section{Pengaruh Model Pembelajaran Level of Inquiry Berbantuan Media Animasi terhadap Pemahaman Konsep Siswa}

Berdasarkan hasil uji hipotesis, secara umum model pembelajaran yang digunakan memberikan pengaruh secara signifikan terhadap nilai pemahaman konsep siswa. Pengaruh terbesar terletak pada kelas eksperimen B yang mana dapat dibuktikan dengan nilai Asym. Sig. sebesar 0,000. Selain memiliki pengaruh yang besar pada kelas tersebut juga memberikan perbedaan hasil terhadap kelas eksperimen A. Namun, kelas eksperimen A tidak signifikan bila dibandingkan dengan kelas kontrol. Perbedaan nilai pemahaman konsep siswa tidak hanya dapat dibedakan berdasarkan hasil uji hipotesis saja. Perbedaan nilai tersebut dapat juga dibedakan dengan menggunakan nilai rata-ratanya. Nilai rata-rata 59,47; 44,09 dan 44 berurutan untuk kelas eksperimen B, A, dan kontrol.

Pada dasarnya animasi statis pengaruhnya tidak sebesar pada animasi dinamis. Penelitian terdahulu menyebutkan bahwa dengan menggunakan animasi dinamis pemahaman konsepnya lebih baik dibandingkan dengan menggunakan animasi statis dan tanpa menggunakan media animasi (Khoiroh, Santosa, Ramli, \& Estiningsih, 2017).

\section{SIMPULAN}

Secara umum maupun secara khusus berpikir kritis siswa tidak memiliki perbedaan yang signifikan ditinjau dari model pembelajarannya. Perbedaan hanya dapat dilihat berdasarkan rata-ratanya. Rata-ratanya secara berurutan adalah kelas kontrol, eksperimen A dan B. Secara umum dan khusus terdapat pengaruh perlakuan terhadap pemahaman konsep siswa. Pengaruh terbesar terdapat pada kelas yang dibelajarkan dengan model Level of Inquiry dengan berbantuan animasi dinamis. Sebaiknya untuk peneliti selanjutnya sebaiknya digunakan sampel yang sudah terlatih menggunakan model pembelajaran inkuiri supaya hasilnya lebih baik. 


\section{DAFTAR RUJUKAN}

Agustin, Y., Fadiawati, N., \& Tania, L. (2017). Peningkatan Keterampilan Berpikir Kritis Siswa pada Materi Laju Reaksi melalui Pendekatan Saintifik. Jurnal Pendidikan dan Pembelajaran Kimia, 5(3), 98-112.

Ardiansyah, M. (2013). Keefektifan Gambar Statis, Gambar Dinamis Ball-and-Stick, dan Model Molekul Sederhana Dibuat dari Jarum Pentul pada Pembelajaran Bentuk dan Kepolaran Molekul. Jurnal Pendidikan Sains, 1(3), 307-314.

Arief, M. K., \& Utari, S. (2015). Implementation of Levels of Inquiry on Science Learning to Improve Junior High School Student's Scientific Literacy. Jurnal Pendidikan Fisika Indonesia, 11(2), 117-125.

Ariyanti, N. D., \& Masykuri, M. (2017). Peningkatan Kemampuan Berpikir Kritis dan Prestasi Belajar Siswa pada Materi Stoikiometri dengan menggunakan Model Pembelajaran Problem Solving Berbantuan Modul di Kelas X MIA 2 SMA Negeri 1 Banyudono Tahun Pelajaran 2015 / 2016. Jurnal Pendidikan Kimia, 6(1), 62-68.

Barak, M., \& Hussein, F. R. (2013). Integrating Model-Based Learning and Animations for Enhancing Students ’ Understanding of Proteins Structure and Function. Research in Science Education, 43, 619-636. https://doi.org/10.1007/s11165-012-9280-7

Bell, R. L., Maeng, J. L., \& Binns, I. C. (2013). Learning in Context: Technology Integration in a Teacher Preparation Program Informed by Situated Learning Theory. Journal of Research in Science Teaching, 50(3), 348-379. https://doi.org/10.1002/tea.21075

Christopher Smith, K., \& Villarreal, S. (2015). Using Animations in Identifying General Chemistry Students' Misconceptions and Evaluating Their Knowledge Transfer Relating to Particle Position in Physical Changes. Chemistry Education Research and Practice, 16(2), 273-282. https://doi.org/10.1039/c4rp00229f

Dona, M. M., Yeni, L. F., \& Nurdini, A. (2013). Pengaruh Media Animasi dan Kemampuan Awal Siswa SMA terhadap Hasil Belajar Sistem Gerak Manusia. Jurnal Pendidikan dan Pembelajaran Untan.

Hendriani. (2016). Pengaruh Model Pembelajaran Inkuiri Terbimbing Berbantuan Media Animasi terhadap Hasil Belajar Kelas VIII Semester I MTs Miftahul Jannah Prodi Tadris Biologi 1437 H / 2016 M. Skripsi tidak diterbitkan. IAIN Palangkaraya.

Kelly, R. M., Akaygun, S., HAnsen, S. J., \& Cerdas, V. (2013). Chemistry Education Research and Practice. Chemistry Education Research and Practice, 1-21. https://doi.org/10.1039/C6RP00240D

Khoiroh, M. N., Santosa, S., Ramli, M., \& Estiningsih, D. E. (2017). The Effect Static and Dynamic Media on Human Reproductive System to Student Conceptual Understanding. Proceeding Biology Education Conference, 14(1), $449-454$.

Komara, D. I., Ertikanto, C., \& Rosidin, U. (2017). Pengaruh Media Pembelajaran Interaktif Model Tutorial Materi Impuls dan Momentum terhadap Kemampuan Berpikir Kritis. Jurnal Pembelajara FISIKA Universitas Lampung, 78(1), 81-90.

Liliawati, W., \& Hidayat, R. (2013). Analisis Kemampuan Inkuiri dan Hasil Belajar Siswa Sekolah Menengah Pertama melalui Model Pembelajaran berbasis Model Hierarki of Inquiry. Prosiding Pertemuan Ilmiah XXVII HFI Jateng \& DIY, (08530823), 107-110.

Nabilah, A. Y., \& Laksmiwati, D. (2018). Analisis Tingkat Pemahaman Konsep Siswa Kelas XI IPA SMAN 3 Mataram Menggunakan One Tier dan Two Tier Test Materi Kelarutan dan Hasil. Jurnal Pijar MIPA, VII(2), 64-69. https://doi.org/10.29303/jpm.v8i2.80

Nyachwaya, J. M. (2016). Research and Practice Understanding and Language Fluency : Acid - Base Neutralization and Conductometry. Chemistry Education Research and Practice. https://doi.org/10.1039/C6RP00015K

Pekdağ, B. (2010). Alternative Methods in Learning Chemistry: Learning with Animation, Simulation, Video, and Multimedia. Journal of Turkish Science Education, 7(2), 111-118.

Saputra, H., Kade, A., \& Hatibe, A. (2017). Pengaruh Model Pembelajaran Levels of Inquiry ( LOI ) terhadap Pemahaman Konsep Fisika Siswa Kelas X SMA Negeri 3 Sigi. Jurnal Pendidikan Fisika Tadulako, 5(4), 21-26.

Supasorn, S., \& Promarak, V. (2014). Research and Practice Implementation of 5E Inquiry Incorporated with Analogy Learning Approach to Enhance Conceptual. Chemistry Education Research and Practice. https://doi.org/10.1039/C4RP00190G

Treagust, D., Chittleborough, G., \& Mamiala, T. (2010). The role of Submicroscopic and Symbolic Representations in Chemical Explanations. International Journal of Science Education, 25(11), 1353-1368. https://doi.org/10.1080/0950069032000070306

Turkoguz, S. (2012). Learn to Teach Chemistry Using Visual Media Tools. Chemistry Education Research and Practice, 13(4), 401-409. https://doi.org/10.1039/c2rp20046e

Utami, B., Saputro, S., Masykuri, M., \& Widoretno, S. (2017). Critical Thinking Skills Profile of High School Students in Learning Chemistry. International Journal of Science and Applied Science: Conferene Series, 1(2), 124-130. https://doi.org/10.20961/ijsascs.v1i2.5134

Wenning, C. J. (2012). Levels of Inquiry : Using Inquiry Spectrum Learning Sequences to Teach Science. Journal Physic Tchr. Education, 5(January), 11-20.

Wenning, C. J., Ed, D., Khan, M. A., Lecturer, S., Khan, A., \& Secondary, H. (2011). Levels of Inquiry Model of Science Teaching : Learning Sequences to Lesson Plans. Journal Physic Education, 6(2), 17-20.

Wisdawati, A. W., \& Sulistyowati. (2014). Metode Pembelajaran IPA. Jakarta: Bumi Aksara. 